\title{
TU/e EmonONEN

\section{Computer modelling studies of defect structures and migration mechanisms in yttrium aluminium garnet}

\section{Citation for published version (APA):}

Schuh, L. H., Metselaar, R., \& Catlow, C. R. A. (1991). Computer modelling studies of defect structures and migration mechanisms in yttrium aluminium garnet. Journal of the European Ceramic Society, 7(2), 67-74. https://doi.org/10.1016/0955-2219\%2891\%2990002-H

DOI:

10.1016/0955-2219\%2891\%2990002-H

Document status and date:

Published: 01/01/1991

\section{Document Version:}

Publisher's PDF, also known as Version of Record (includes final page, issue and volume numbers)

\section{Please check the document version of this publication:}

- A submitted manuscript is the version of the article upon submission and before peer-review. There can be important differences between the submitted version and the official published version of record. People interested in the research are advised to contact the author for the final version of the publication, or visit the $\mathrm{DOI}$ to the publisher's website.

- The final author version and the galley proof are versions of the publication after peer review.

- The final published version features the final layout of the paper including the volume, issue and page numbers.

Link to publication

\section{General rights}

Copyright and moral rights for the publications made accessible in the public portal are retained by the authors and/or other copyright owners and it is a condition of accessing publications that users recognise and abide by the legal requirements associated with these rights.

- Users may download and print one copy of any publication from the public portal for the purpose of private study or research.

- You may not further distribute the material or use it for any profit-making activity or commercial gain

- You may freely distribute the URL identifying the publication in the public portal.

If the publication is distributed under the terms of Article 25fa of the Dutch Copyright Act, indicated by the "Taverne" license above, please follow below link for the End User Agreement:

www.tue.nl/taverne

Take down policy

If you believe that this document breaches copyright please contact us at:

openaccess@tue.nl

providing details and we will investigate your claim. 


\title{
Computer Modelling Studies of Defect Structures and Migration Mechanisms in Yttrium Aluminium Garnet
}

\author{
L. Schuh, ${ }^{*}$ R. Metselaar \\ Eindhoven University of Technology, Laboratory for Solid State Chemistry and Materials Science, 5600 MB Eindhoven, \\ The Netherlands
}

$\&$

C. R. A. Catlow $\ddagger$

Chemistry Department, University of Keele, Keele, Staffordshire ST5 5BG, UK

(Received 14 May 1990; accepted 24 September 1990)

\begin{abstract}
Using computer simulation techniques the defect structure, the ionic migration mechanisms, the solution enthalpies and the oxidation/reduction behaviour of yttrium aluminium garnet was investigated. Based on the saddle point energies a continuous path for a migrating anion was identified. The calculated results for the solution energies of $\mathrm{MgO}$ and $\mathrm{CaO}$ imply that these oxides have a low solubility in the garnet.
\end{abstract}

Die Defektstruktur, die Mechanismen der Ionenwanderung, die Lösungsenthalpien und das Oxidations-/Reduktions-Verhalten von Ytttrium Aluminium Granat wurden mittels ComputerSimulation untersucht. Durch den Vergleich der Übergangsenergien für verschiedene Ionensprünge in den Untergittern wurden mögliche Diffusionswege der Ionen untersucht. Berechnete Lösungsenthalpien für $\mathrm{MgO}$ und $\mathrm{CaO}$ weisen auf deren geringe Löslichkeit hin.

On a étudié par simulation sur ordinateur la structure des défauts, les mécanismes de migration ionique, les enthalpies de dissolution et le comportement en oxydoréduction d'un grenat yttrium aluminium. En

\footnotetext{
* Present address: Asea Brown Boveri Corporate Research, 6900 Heidelberg, FRG.

¥ Present address: Davy Faraday Research Laboratory, Royal Institution, 21 Albermarle Street, London W1X 4BS, UK.
}

comparant les énergies de transition des différentes migrations ioniques dans les sous-réseaux, on a pu établir les parcours possibles de diffusion des ions. Les valeurs des énergies de dissolution calculées pour $\mathrm{MgO}$ et $\mathrm{CaO}$ impliquent que ces oxydes aient une faible solubilité dans le grenat.

\section{Introduction}

The properties of crystalline matter, such as functional or structural ceramics, are, to a large extent, determined by the presence of ionic defects. In recent years there has been a considerable success in the calculation of defect formation energies, ionic migration energies, redox energies, etc., in ionic crystals (e.g. $\mathrm{Al}_{2} \mathrm{O}_{3},{ }^{1,2} \mathrm{MgO},{ }^{3} \mathrm{Fe}_{2} \mathrm{O}_{3},{ }^{4} \mathrm{TiO}_{2}$, ${ }^{1}$ $\mathrm{BaTiO}_{3},{ }^{5} \mathrm{La}_{2} \mathrm{CuO}_{4}{ }^{6}$ ). The present study reports an application of these methods to the garnet $\mathrm{Y}_{3} \mathrm{Al}_{5} \mathrm{O}_{12}$, yttrium aluminium garnet (YAG). Single-crystalline YAG has been well known as a host material for laser-emitting ions since $1964 .^{7}$ Later in the 1970s it was found that YAG powders can be sintered to translucency. ${ }^{8,9}$ Experiments performed in the 1980 s revealed that translucent YAG ceramics have a better corrosion resistance against hot alkali vapour than translucent alumina. ${ }^{10}$ This makes YAG a candidate material to produce high-pressure sodium lamp envelopes. Furthermore the optical transmittance and the mechanical properties of YAG are better than those of translucent alumina.

Journal of the European Ceramic Society 0955-2219/91/\$3.50 (C) 1991 Elsevier Science Publishers Ltd, England. Printed in Great Britain 
In this paper studies on the transport properties and defect chemistry of YAG ceramics $^{11,12}$ are continued, by performing Mott-Littleton defect calculations available in the CASCADE computer code. ${ }^{13}$ Point defect formation energies, the energetics of redox processes, solution enthalpies for $\mathrm{CaO}$ and $\mathrm{MgO}$ in YAG, the energetics of defect clustering and saddle point energies for elementary diffusion steps in the YAG lattice will be discussed.

\section{Simulation Methods}

The static lattice simulation technique (which refers to methods that do not take into account directly the thermal motion of the crystal lattice) used in this paper makes use of the generalized Mott-Littleton method available in the computer code CASCADE. ${ }^{14,15}$ For ionic materials the theory of lattice defects is largely concerned with two main problems:

(1) The derivation of suitable interatomic potentials (in strongly ionic crystals two body potentials are generally adequate).

(2) The treatment of the lattice relaxation around a lattice defect.

For the first of these problems, there are two different approaches. One involves the use of Born-Mayer or Buckingham potentials which are parameterized empirically by fitting the calculated perfect lattice properties, such as lattice energy, dielectric and elastic constants, to experimental values. The Buckingham potential is given by

$$
V(r)=A \exp (r / \rho)-C r^{-6}
$$

where $r$ is the distance between a pair of ions. The parameters $A, \rho$ and $C$ must be assigned for each probable ion-ion interaction. By this procedure empirical short-range potentials are obtained; they are used here. Three potentials for the undoped YAG were thought to be necessary to describe fully the system: $\mathrm{Y}^{3+}-\mathrm{O}^{2-}, \mathrm{Al}^{3+}-\mathrm{O}^{2-}$ and an $\mathrm{O}^{2-}-\mathrm{O}^{2-}$ potential. Cation-cation interactions were neglected as it was thought that the distance involved meant that this interaction is negligible for this structure. For doped YAG additionally the $\mathrm{Ca}^{2+}-\mathrm{O}^{2-}$ and the $\mathrm{Mg}^{2+}-\mathrm{O}^{2-}$ potentials were used. An alternative approach (not used in the present study) is to calculate the interatomic potentials using the electron-gas method ${ }^{16}$ or using ab-initio Hartree-Fock techniques. ${ }^{17}$

An essential feature of the computer simulation of defective ionic solids is the inclusion of ionic polarization. Despite its simplicity the shell model ${ }^{18}$ remains the most effective way of doing this.

The second question, dealing with the lattice relaxation around a defect, is treated in terms of a model developed by Mott $\&$ Littleton $^{14}$ and by Lidiard \& Norgett ${ }^{19}$ and Norgett. ${ }^{20}$ The basic idea behind this model is the equilibration of the total energy of the crystal by independent relaxation of cores and shells of the ions around the lattice defect. A detailed discussion of the simulation procedure is given by Catlow, Dixon \& Mackrodt $^{16}$ and Catlow. ${ }^{15}$

\section{The Garnet Lattice}

Garnets have a cubic body-centred lattice, space group Ia3d. The cations occupy $24 c$-sites with dodecahedral coordination, $16 a$-sites with octahedral coordination and $24 d$-sites with tetrahedral oxygen coordination. There are 8 formula units $\left\{C_{3}\right\}\left[A_{2}\right]\left(D_{3}\right) O_{12}$ per unit cell, where $O$ denotes oxygen and the different brackets \{\}$,[]$ and () symbolize cations in the dodecahedral, octahedral and tetrahedral sites respectively. In YAG the $\mathrm{Al}$ ions occupy both the tetrahedral and the octahedral sites, while $\mathrm{Y}$ is located on the dodecahedral sites. The formula can therefore be written as $\left\{\mathrm{Y}_{3}\right\}\left[\mathrm{Al}_{2}\right]\left(\mathrm{Al}_{3}\right) \mathrm{O}_{12}$. The lattice constant is $a=$ $12 \cdot 000 \AA$.

Table 1. Input potential parameters and shell constants for YAG

\begin{tabular}{|c|c|c|c|c|c|}
\hline Ion & $A(\mathrm{eV})$ & $\rho(A)$ & $Y^{+}(|e|)$ & $K^{+}\left(e V \AA^{-2}\right)$ & $C\left(e V \AA^{-6}\right)$ \\
\hline $\mathrm{O}^{2-}-\mathrm{O}^{2-}$ & 22664.0 & $0 \cdot 149$ & 0.8481 & 74.92 & $27 \cdot 88[1]$ \\
\hline $\mathrm{Y}^{3+}-\mathrm{O}^{2-}$ & $1345 \cdot 1$ & 0.3491 & $-0 \cdot 251$ & $71 \cdot 70$ & $0.0[5]$ \\
\hline $\mathrm{Al}^{3+}-\mathrm{O}^{2-}$ & $1469 \cdot 3$ & $0 \cdot 2991$ & 3.00 & - & 0.0 [1] \\
\hline $\mathrm{Ca}^{2+}-\mathrm{O}^{2-}$ & $1090 \cdot 1$ & 0.3437 & $-1 \cdot 135$ & $110 \cdot 20$ & $0.0 \quad[5]$ \\
\hline $\mathrm{Mg}^{2+}-\mathrm{O}^{2-}$ & $1280 \cdot 1$ & 0.3177 & 2.00 & - & $0 \cdot 0 \quad[5]$ \\
\hline
\end{tabular}

$A$ and $\rho=$ parameters in the equation for the Buckingham potential; $Y^{+}=$charge of the core; $K^{+}=$core-shell spring constant, $C=$ attractive contribution.

Note that all short range potentials were cut-off (i.e. set to zero) for distances larger than $0.6 a$ ( $a=$ lattice parameter). 
Table 2. Calculated and experimental values of crystal properties for $\mathrm{YAG}$ and $\mathrm{Al}_{2} \mathrm{O}_{3}$ (taken from Ref. 1)

\begin{tabular}{|c|c|c|c|c|c|}
\hline \multirow[t]{2}{*}{ Constant } & \multicolumn{2}{|c|}{$Y A G$} & \multirow[t]{2}{*}{ Constant } & \multicolumn{2}{|c|}{$\mathrm{Al}_{2} \mathrm{O}_{3}$} \\
\hline & Calculated & Experimental & & Calculated & Experimental \\
\hline$\varepsilon_{\mathrm{o}}$ & $8 \cdot 1$ & $11 \cdot 0$ & $\begin{array}{l}\varepsilon_{o}^{11} \\
\varepsilon_{33}^{33}\end{array}$ & $\begin{array}{r}9 \cdot 38 \\
11.52\end{array}$ & $\begin{array}{r}9 \cdot 34 \\
11 \cdot 54\end{array}$ \\
\hline$\varepsilon_{x}$ & $2 \cdot 9$ & $3 \cdot 5$ & $\begin{array}{l}\varepsilon_{x}^{011} \\
\varepsilon_{x}^{33}\end{array}$ & $\begin{array}{l}2 \cdot 08 \\
2 \cdot 02\end{array}$ & $3 \cdot 1$ \\
\hline $\begin{array}{l}C_{11}(\mathrm{GPa}) \\
C_{12}(\mathrm{GPa}) \\
C_{44}(\mathrm{GPa}) \\
\text { Lattice } \\
\text { energy }^{a}\end{array}$ & $\begin{array}{l}395 \\
135 \\
117\end{array}$ & $\begin{array}{l}333 \\
113 \\
115\end{array}$ & & $\begin{array}{l}429 \cdot 6 \\
154 \cdot 8 \\
166\end{array}$ & $\begin{array}{l}496 \cdot 9 \\
163 \cdot 6 \\
147 \cdot 4\end{array}$ \\
\hline
\end{tabular}

The experimental data were taken from Refs 22 and 23.

${ }^{a}$ Lattice energy per unit cell in $\mathrm{eV}$ (with 8 formula units of YAG).

\section{Results}

\subsection{Properties of the perfect YAG lattice}

Table 1 gives the potential parameters for the perfect lattice simulation and the shell parameters. The small ions $\mathrm{Al}$ and $\mathrm{Mg}$ are considered to be unpolarizable, while the other ions are treated as polarizable. The polarizability in terms of the coreshell model is introduced by a spring constant $K^{+}$ which characterizes the coupling beiween the core and the massless shell. The potential parameters used in this study are reported in Refs 1 and 5.

The calculated dielectric and elastic constants which were derived by the standard procedure available in the PLUTO subroutine ${ }^{21}$ are given in Table 2. The values are presented for YAG and for $\mathrm{Al}_{2} \mathrm{O}_{3}$ for the sake of comparison $\left(\mathrm{Al}_{2} \mathrm{O}_{3}\right.$ is a relatively simply structured material, for which extensive simulation data are available ${ }^{1,2}$ ).

Calculated perfect lattice data for YAG given in Table 2 are sufficiently close to the experimental values to demonstrate the reliability of the potentials used.

\subsection{Basic point defect formation energies}

The basic defect reactions are the formation of simple point defects. In this section the formation energies of cation and anion vacancies and interstitials are considered; the calculated values are given in Table 3.

From single point defect formation energies a first approximation to the Schottky and Frenkel energies can be derived. Taking the vacancy formation energies for yttrium, aluminium (on the $a$ - and $d$ sites) and oxygen leads to a Schottky energy (to form a complete Schottky multiplet) of $106.3 \mathrm{eV}$ $(10257 \mathrm{~kJ} / \mathrm{mol}), \dagger$ which gives $5.32 \mathrm{eV}$ per defect $(513 \mathrm{~kJ} / \mathrm{mol})$. The energy per defect to form a Frenkel pair lies between 7 and $10 \mathrm{eV}$ (675 and $965 \mathrm{~kJ} / \mathrm{mol}$; see Table 4). Here the energies of isolated defects are taken into account; to consider obtainable physical processes further work is necessary.

However, the calculations indicate that Schottky

$\uparrow$ The Schottky energy is the energy necessary to remove a complete formula unit YAG from the crystal interior (the sum of the defect formation energies minus the lattice energy).

Table 3. Formation energies for point defects in YAG

\begin{tabular}{|c|c|c|c|}
\hline \multirow[t]{2}{*}{ Defect } & \multirow[t]{2}{*}{ Symbol } & \multicolumn{2}{|c|}{ Defect formation energy per defec } \\
\hline & & $e V$ & $\mathrm{~kJ} / \mathrm{mol}$ \\
\hline Oxygen vacancy & $\mathrm{V}_{\mathrm{o}}^{*}$ & $22 \cdot 35$ & 2157 \\
\hline Yttrium vacancy & $V_{y}^{\prime \prime \prime}$ & $46 \cdot 5$ & 4487 \\
\hline Yttrium interstitial & $Y_{i}^{y} \cdots$ & $-25 \cdot 62$ & -2472 \\
\hline Aluminium vacancy on $d$-site & $V_{A 1}^{\prime \prime \prime}$ & 58.90 & 5683 \\
\hline Aluminium vacancy on $a$-site & $V_{A_{1}}^{\prime \prime \prime}$ & $60 \cdot 24$ & 5813 \\
\hline Aluminium interstitial & $\mathrm{Al}_{\mathrm{i}}^{\cdots}$ & $-45 \cdot 11$ & -4353 \\
\hline Ca-substitutional & $\mathrm{Ca}_{Y}^{\prime}$ & $23 \cdot 0$ & 2219 \\
\hline Mg-substitutional & $\mathrm{Mg}_{\mathbf{Y}}^{\prime}$ & $18 \cdot 3$ & 1766 \\
\hline
\end{tabular}


Table 4. The formation energies for combined defects in YAG

\begin{tabular}{|c|c|c|}
\hline & \multicolumn{2}{|c|}{ Defect formation energy } \\
\hline & $e V$ & $\mathrm{~kJ} / \mathrm{mol}$ \\
\hline Schottky energy & $5 \cdot 32$ & 513 \\
\hline Yttrium Frenkel & $10 \cdot 44$ & 1007 \\
\hline \multicolumn{3}{|l|}{ Aluminium Frenkel } \\
\hline From an $a$-site & $7 \cdot 57$ & 730 \\
\hline From a $d$-site & $6 \cdot 88$ & 664 \\
\hline
\end{tabular}

disorder should be energetically favoured compared with Frenkel disorder. The result is in accordance with the conclusion derived by others on the basis of experimental or theoretical work. ${ }^{24}$

\subsection{Foreign cations in YAG}

The properties of crystalline materials are strongly influenced by the presence of impurities. These ions occupy specific sites depending on their radius. $\mathrm{Ca}^{2+}$ and $\mathrm{Mg}^{2+}$ both are thought to occupy $c$-sites.

The energies for replacing an $\mathrm{Y}$ ion by a $\mathrm{Mg}^{2+}$ and $\mathrm{a} \mathrm{Ca}^{2+}$ ion are $18.3 \mathrm{eV}(1766 \mathrm{~kJ} / \mathrm{mol})$ and $23.0 \mathrm{eV}(2219 \mathrm{~kJ} / \mathrm{mol}$ ) respectively (see Table 3$)$. It is noted that these energies refer to processes with respect to ions at infinity. Thus for Ca-substitution the calculated energy refers to the process

$$
\mathrm{Y}_{\mathrm{Y}}^{\mathrm{x}}+\mathrm{Ca}_{\text {(vacuum) }}^{2+} \longrightarrow \mathrm{Ca}_{\mathbf{Y}}^{\prime}+\mathrm{Y}_{\text {(vacuum) }}^{3+}
$$

Using these values it is possible to calculate the solution enthalpies for $\mathrm{MgO}$ and $\mathrm{CaO}$ in the $\mathrm{YAG}$ lattice. The substitutional energy has to be considered together with an appropriate charge compensating defect and a full Born-Haber cycle evaluated for the solution reactions. For low valence ions compensation can be provided by anion vacancies, by cation interstitials and by a selfcompensation mechanism. Calculations show that anion vacancy compensation has the lowest energy in YAG. The reaction for the vacancy compensated dissolution of $\mathrm{CaO}$ is

$$
\mathrm{CaO}+\mathrm{Y}_{\mathrm{Y}}^{\mathrm{x}}+1 / 2 \mathrm{O}_{\mathrm{o}}^{\mathrm{x}} \leftrightarrow \mathrm{Ca}_{\mathrm{Y}}^{\prime}+1 / 2 \mathrm{~V}_{\mathrm{o}}^{*}+1 / 2 \mathrm{Y}_{2} \mathrm{O}_{3}
$$

in which $\mathrm{Y}_{2} \mathrm{O}_{3}$ refers to yttrium oxide on the surface of the crystal. So, to calculate the energetics of the reaction given in eqn (2), the lattice energies for $\mathrm{CaO}$, $\mathrm{MgO}$ and $\mathrm{Y}_{2} \mathrm{O}_{3}$ are needed, as well as the point defect formation energies. The lattice energies for $\mathrm{CaO}$ and $\mathrm{MgO}$ were previously calculated, applying the same potentials as used in the present study, as $36.0 \mathrm{eV}(3474 \mathrm{~kJ} / \mathrm{mol})$ and $40.74 \mathrm{eV}(3931 \mathrm{~kJ} / \mathrm{mol}){ }^{25}$ For $\mathrm{Y}_{2} \mathrm{O}_{3}$ the lattice energy is calculated to be $135.5 \mathrm{eV}(13074 \mathrm{~kJ} / \mathrm{mol})$. The solution enthalpy $E_{\mathrm{Ca}}(\mathrm{sol})$ for $\mathrm{CaO}$ in $\mathrm{YAG}$ was calculated by taking the defect formation energies given in Table 3:

$$
\begin{aligned}
E_{\mathrm{Ca}}(\mathrm{sol}) & =E(\mathrm{CaO})+E\left(\mathrm{Ca}_{\mathrm{Y}}^{\prime}\right)+1 / 2 E\left(\mathrm{~V}_{\mathrm{o}}^{*}\right) \\
& -1 / 2 E\left(\mathrm{Y}_{2} \mathrm{O}_{3}\right)=2 \cdot 48 \mathrm{eV}(239 \mathrm{~kJ} / \mathrm{mol})
\end{aligned}
$$

using the known values of $E(\mathrm{CaO})$ and $E\left(\mathrm{Y}_{2} \mathrm{O}_{3}\right)$, the lattice energies of $\mathrm{CaO}$ and $\mathrm{Y}_{2} \mathrm{O}_{3}$. From eqn (3) a value of $2.48 \mathrm{eV}(239 \mathrm{~kJ} / \mathrm{mol})$ per $\mathrm{CaO}$ is obtained for the solution enthalpy for $\mathrm{CaO}$ in YAG. An analogous reaction can be written for $\mathrm{MgO}$, which leads to a solution enthalpy of $2.52 \mathrm{eV}$ per $\mathrm{MgO}$ (or $243 \mathrm{~kJ} / \mathrm{mol} \mathrm{MgO}$ ).

\subsection{Clustering effects}

In a crystal lattice which is doped with aliovalent ions clustering of defects may occur, since defects carrying opposite charges attract each other. Thus positively charged oxygen vacancies $\mathrm{V}_{0}^{*}$ and negatively charged substitutionals $\mathrm{Ca}_{\mathbf{Y}}^{\prime}$ or $\mathrm{Mg}_{\mathbf{Y}}^{\prime}$ can interact by forming stabilized defect clusters:

$$
\mathrm{V}_{\mathrm{o}}^{\cdot}+\mathrm{Ca}_{\mathbf{Y}}^{\prime} \longleftrightarrow\left(\mathrm{V}_{\mathrm{o}}^{\cdot \cdot} \mathrm{Ca}_{\mathrm{Y}}^{\prime}\right)^{\cdot}
$$

and

$$
\mathrm{V}_{\mathrm{o}}^{\cdot *}+2 \mathrm{Ca}_{\mathbf{Y}}^{\prime} \longleftrightarrow\left(\mathrm{Ca}_{\mathbf{Y}}^{\prime} \mathrm{V}_{\mathrm{o}}^{\cdot \cdot} \mathrm{Ca}_{\mathbf{Y}}^{\prime}\right)^{\mathrm{x}}
$$

The defect cluster $\left(\mathrm{V}_{\mathrm{o}}^{\cdot \cdot} \mathrm{Ca}_{\mathbf{Y}}^{\prime}\right)^{\prime}$, carrying a positive charge, has an association energy of $1 \mathrm{eV}$, while the neutral defect trimer $\left(\mathrm{Ca}_{\mathbf{Y}}^{\prime} \mathrm{V}_{\mathbf{0}}^{\cdot \cdot} \mathrm{Ca}_{\mathbf{Y}}^{\prime}\right)^{\mathrm{x}}$ is bound by an energy of $1.7 \mathrm{eV}$. The direct effect of such defect clustering is a reduction of the concentration of free oxygen vacancies; the $\mathrm{V}_{\mathrm{o}}$ " concentration is lowered by the amount which is bound by the $\mathrm{Ca}_{\mathbf{Y}}^{\prime}$ (or $\mathrm{Mg}_{\mathbf{Y}}^{\prime}$ ). Defect clustering will also result in more negative solution energies.

\subsection{Energies of oxidation and reduction}

Following the discussion of electronic disorder in YAG, which was recently published as a part of a more comprehensive paper on an experimental investigation of the defect chemistry of doped YAG,${ }^{12}$ it is appropriate now to consider calculated energies of oxidation and reduction, as these control the level of non-stoichiometry in the oxides. The processes concerned are

$$
\mathrm{O}_{\mathrm{o}}^{\mathrm{x}} \longleftrightarrow \mathrm{V}_{\mathrm{o}}^{\cdot \cdot}+1 / 2 \mathrm{O}_{2}+2 \mathrm{e}^{\prime}\left(E_{\text {red }}\right)
$$

which is the equilibration of YAG at low oxygen partial pressure, and

$$
1 / 2 \mathrm{O}_{2}+\mathrm{V}_{\mathrm{o}}^{\cdot \cdot} \longleftrightarrow \mathrm{O}_{\mathrm{o}}^{\mathrm{x}}+2 \mathrm{~h}^{\cdot}\left(E_{\mathrm{ox}}\right)
$$

which represents the hole formation in YAG doped with low valence ions, which was investigated experimentally in a previous study. ${ }^{12}$ This reaction is 
the most probable one. $E_{\text {red }}$ and $E_{\mathrm{ox}}$ are oxidation and reduction energies respectively.

Both holes and electrons are treated in terms of the small polaron model. It is assumed that the electron is located on a lattice aluminium ion and the lattice distorts around the centre, i.e. the following reaction is assumed for the electron formation

$$
\mathrm{Al}_{\mathrm{A} 1}^{\mathrm{x}}+\mathrm{e}^{\prime} \longleftrightarrow \mathrm{Al}_{\mathrm{A} 1}^{\prime}\left(E_{\mathrm{e}}\right)
$$

The polaron formation energy $E_{\mathrm{e}}$ can be derived by combining the energy calculated for replacing $\mathrm{Al}^{3+}$ by $\mathrm{Al}^{2+}(31.6 \mathrm{eV} ; 3049 \mathrm{~kJ} / \mathrm{mol})$ with the third ionization potential of $\mathrm{Al}(28.53 \mathrm{eV} ; 2753 \mathrm{~kJ} / \mathrm{mol}){ }^{26}$ Thus for $E_{\mathrm{e}}$ an energy of $3.07 \mathrm{eV}(296 \mathrm{~kJ} / \mathrm{mol})$ is obtained. The reduction energy $E_{\text {red }}$, which is a combination of eqn (6) and eqn (8), symbolized by eqn (6a)

$$
\mathrm{O}_{\mathrm{o}}^{\mathrm{x}}+2 \mathrm{Al}_{\mathrm{A} 1}^{\mathrm{x}} \longleftrightarrow \mathrm{V}_{\mathrm{o}}^{\cdot *}+1 / 2 \mathrm{O}_{2}+2 \mathrm{Al}_{\mathrm{A} 1}^{\prime}
$$

is given by

$$
\begin{aligned}
E_{\text {red }}=E\left(\mathrm{~V}_{\mathrm{o}}^{*}\right)-1 / 2 E_{\text {Diss }}+E_{12}+2 E_{\mathrm{e}} \\
=18.63 \mathrm{eV}(1800 \mathrm{~kJ} / \mathrm{mol})
\end{aligned}
$$

where $E\left(V_{\mathrm{o}}^{*}\right)$ is the oxygen vacancy formation energy, $E_{\text {Diss }}$ the dissociation energy for $\mathrm{O}_{2}(5 \cdot 16 \mathrm{eV}$; $498 \mathrm{~kJ} / \mathrm{mol}$ ), $E_{12}$ the sum of the first two electron affinities of oxygen $(-7.28 \mathrm{eV} ;-702 \mathrm{~kJ} / \mathrm{mol})^{27}$ and $E_{\mathrm{e}}$ the polaron formation energy estimated previously. This result, giving a high energy for the reduction, confirms that it is not possible to reduce YAG significantly.

If, however, YAG doped with divalent ions, e.g. $\mathrm{Ca}^{2+}$ or $\mathrm{Mg}^{2+}$ to create oxygen vacancies (see eqn (7)) is considered, the oxidation energy $E_{\text {ox }}$ can be calculated following eqn (11). The released holes are again treated in terms of the formation of small polarons according to the reaction

$$
\mathrm{O}_{\mathrm{o}}^{\mathrm{x}}+\mathrm{h}^{\cdot} \longleftrightarrow \mathrm{O}_{\mathrm{o}}^{\prime}\left(E_{\mathrm{h}}\right)
$$

with $E_{\mathrm{h}}$ the polaron formation energy.

The energy $E\left(\mathrm{O}_{\mathrm{o}}^{\prime}\right)$ for replacing $\mathrm{O}_{\mathrm{o}}^{\mathrm{x}}$ by $\mathrm{O}_{\mathrm{o}}^{\prime}$ was calculated to be $18.6 \mathrm{eV}(1795 \mathrm{~kJ} / \mathrm{mol})$ per defect. This energy has to be combined with the second electron affinity of oxygen $(-8.75 \mathrm{eV} ;-844 \mathrm{~kJ} / \mathrm{mol})$ to obtain the polaron formation energy $E_{\mathrm{h}}=9.85 \mathrm{eV}$ $(950 \mathrm{~kJ} / \mathrm{mol})$. The energy for the oxidation reaction $E_{\text {ox }}$, given by a combination of eqn (7) and eqn (10), is

$$
\begin{aligned}
E_{\mathrm{ox}}=-E\left(\mathrm{~V}_{\mathrm{o}}^{*}\right)+1 / 2 E_{\text {Diss }}-E_{12}+2 E_{\mathrm{h}} \\
=7 \cdot 2 \mathrm{eV}(695 \mathrm{~kJ} / \mathrm{mol})
\end{aligned}
$$

For the doped material a clustering of defects leading to $\left(\mathrm{Ca}_{Y}^{\prime} \mathrm{O}_{\mathrm{o}}^{\prime}\right)^{\mathrm{x}}$ has to be considered. Such an

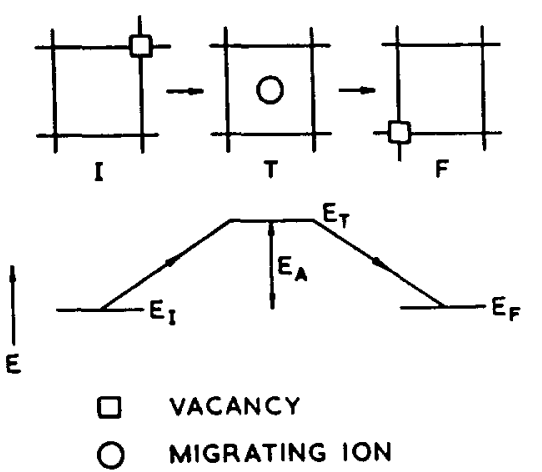

Fig. 1. Schematic diagram for ion migration.

associate is stabilized by $0.31 \mathrm{eV}$, so the redox energy is altered by this amount. The energy is rather high, suggesting that divalent doped YAG will resist oxidation and be only a poor p-type semiconductor.

\subsection{Saddle point energies}

Saddle point energies were calculated for ions jumping from regular lattice sites to adjacent vacant sites. These represent the activation energy for a single ion diffusion step (as given in Fig. 1). Recent studies on several materials revealed that transition states for jumping ions can have large displacements out of the plane of the adjacent lattice sites. ${ }^{28}$

\subsubsection{Migrating oxygen ions}

To investigate the saddle point energy and the saddle point displacement for jumping oxygen ions the energy of the transition state for an oxygen ion jumping from an $\mathrm{h}$-site to a vacant $\mathrm{h}$-site on the same tetrahedron following a straight line (see Fig. 2) was calculated. This energy was found to be $2.09 \mathrm{eV}$ $(202 \mathrm{~kJ} / \mathrm{mol})$.

Considering the position of the regular ions in the region of the lattice surrounding the initial and the final positions of the migrating oxygen ion makes clear that the migration path is influenced by the charged lattice ions. The jump along a straight line, as indicated in Fig. 2, is not the path with the lowest

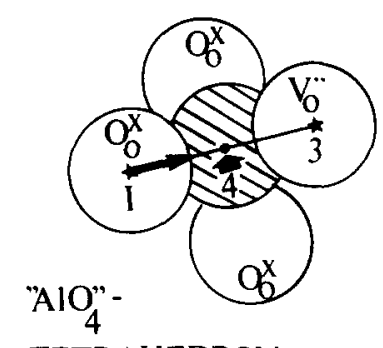

TETRAHEDRON

Fig. 2. Simple geometry for an oxygen ion jumping from a regular site 1 to vacant site 3 on a tetrahedron. Point 4 marks the saddle point for a straight line jump (for the sake of clarity the ionic radii are not drawn to scale). 


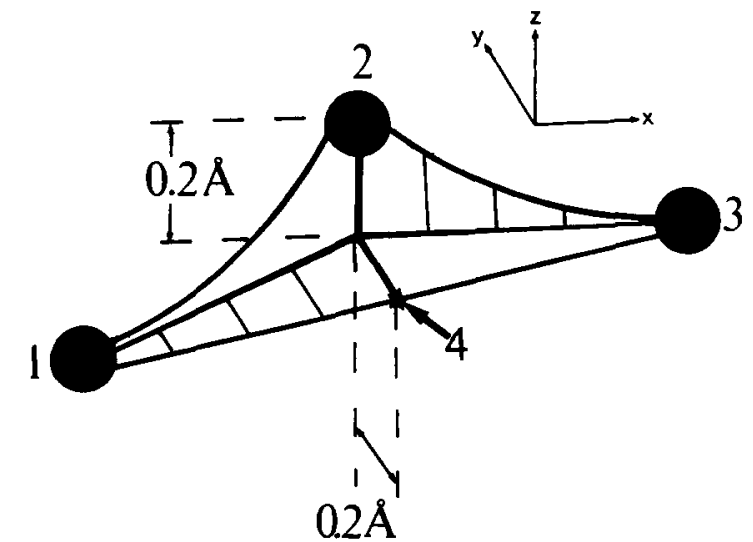

Fig. 3. A moving oxygen ion does not move along a straight line from the start to the final position. Due to interactions with adjacent ions the jumping path is displaced as shown here. Point 4 marks the saddle point for an ion moving along a straight line.

transition energy; a somewhat curved jump geometry is expected.

In order to find this path the saddle point energies of about 50 slightly different positions of the transition point located between the initial and the final position were then calculated. This resulted in a curved jump path with a calculated activation energy of $1.5 \mathrm{eV}(145 \mathrm{~kJ} / \mathrm{mol})$. The saddle point is displaced $0 \cdot 2 \AA$ in the $y$-direction and $0 \cdot 2 \AA$ in the $z$ direction, as depicted in Fig. 3. Thus there is a considerable saddle point displacement for jumping oxygen ions in YAG, which is in agreement with simulation results for other crystalline materials. ${ }^{28}$

By considering the polyhedral model of the garnet structure (a network of tetrahedra and octahedra connected with each other) it becomes clear that within the garnet lattice different anion jumps with different saddle point energies are possible; some of

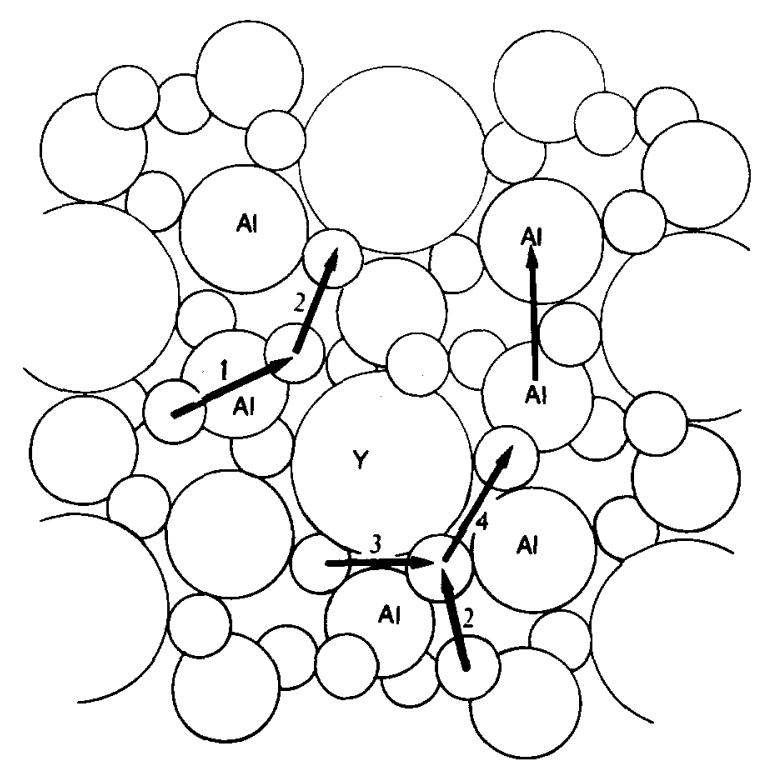

Fig. 4. Projection of a part of the garnet unit cell (for the sake of clarity the ionic radii are not drawn to scale). Possible oxygen jumps and the aluminium jump simulated are indicated.
Table 5. Saddle point energies for different jump paths

\begin{tabular}{ccc}
\hline Migration path & \multicolumn{2}{c}{ Saddle point energy } \\
\cline { 2 - 3 } & $\mathrm{eV}$ & $\mathrm{kJ} / \mathrm{mol}$ \\
\hline 1 & 2.09 & 202 \\
2 & 1.50 & 145 \\
3 & 3.34 & 322 \\
4 & 1.84 & 178 \\
\hline
\end{tabular}

these jumps are marked in the projection of a part of the unit cell of the garnet lattice in Fig. 4. The calculated saddle point energies for migration along a straight line are given in Table 5. Again a curved migration path having a somewhat lower transition energy than the straight line jump has to be considered. It seems to be justified to assume a transition energy which is about $10-20 \%$ lower for the curved than for the straight jump.

From a consideration of the crystal structure (a three-dimensional model of the garnet lattice should be used) it can be deduced that a combination of jump 2 and jump 4 is sufficient to find a continuous, low energy path for migrating oxygen ions through the YAG lattice. Jump 2 corresponds to migration between tetrahedra (via empty $b$-sites, within the garnet structure, which have the lowest transition energy found). Jump 4 is the migration along an octahedron. The activation energy for the migrating oxygen ion should be determined by the higher of both saddle point energies. This leads to activation energies for migrating oxygen ions of approximately $1.5 \mathrm{eV}(145 \mathrm{~kJ} / \mathrm{mol})$, which is somewhat lower than the activation energy of $2.3 \mathrm{eV}(222 \mathrm{~kJ} / \mathrm{mol})$ and $2 \cdot 1 \mathrm{eV}(203 \mathrm{~kJ} / \mathrm{mol})$ for ionic migration reported by Rotman et al. ${ }^{29}$ and $S$ chuh $^{30}$ for YAG derived from electrical conductivity measurements.

\subsubsection{Migrating Al ions}

The possible jumps for $\mathrm{Al}$ ions are more difficult to study than those for oxygen. A moving $\mathrm{Al}$ ion migrating from a lattice position to an adjacent vacant position has to follow a 'wavy' line; the distance between two $\mathrm{Al}$ ions is much longer than the distance between two adjacent $\mathrm{O}$ ions. An $\mathrm{Al}$ jump from a tetrahedral to an adjacent octahedral site was investigated by checking the energy of an $\mathrm{Al}_{\mathrm{i}} \ldots$ at 20 different positions in the space between the initial and the final position. The saddle point energy for a migrating $\mathrm{Al}$ ion was found to be not lower than $3.5 \mathrm{eV}(338 \mathrm{~kJ} / \mathrm{mol})$. Röschmann derived, by considering the redistribution energy for iron ions between the tetrahedral and octahedral positions in iron garnets, a saddle point energy of $4.5 \mathrm{eV}(405 \mathrm{~kJ} / \mathrm{mol}) .{ }^{31}$ 
The results on the saddle point energies for aluminium and oxygen jumps indicate that oxygen should exhibit a higher mobility in the YAG lattice than $\mathrm{Al}$ ions. The same result followed from diffusion and electrical conductivity experiments performed on pure single crystalline YAG. ${ }^{24,32}$ However, it should be noted that in a recent study it has been shown that the transport properties of polycrystalline $\mathrm{YAG}$ containing $\mathrm{Al}_{2} \mathrm{O}_{3}$ inclusions are governed by the presence of $\mathrm{Al}$ vacancies. ${ }^{12}$

\section{Conclusion}

The authors have applied the technique of computer simulation to derive basic defect properties of YAG. The conclusion of many previous studies that oxygen vacancies are the most probable point defects is supported by our theoretical study; the formation of $\mathrm{Al}$ vacancies needs a much higher energy than the formation of $\mathrm{O}$ vacancies. With respect to the calculated energies for isolated defects it may be stated to a first approximation that Schottky defects are easier to form than Frenkel defects. Considerations of realistic physical processes should be performed in the future.

By considering saddle point energies the authors have determined a continuous path for a migrating oxygen ion exhibiting an activation energy of approximately $1.5 \mathrm{eV}(145 \mathrm{~kJ} / \mathrm{mol})$, which is somewhat lower than experimental activation energies for the ionic conductivity due to migrating oxygen ions.

Based on the calculated energy to form $\mathrm{Ca}_{\mathrm{Y}}^{\prime}$ and $\mathrm{Mg}_{\mathrm{Y}}^{\prime}$ substitutionals the authors have derived the solution enthalpy for $\mathrm{CaO}$ and $\mathrm{MgO}$ in the $\mathrm{YAG}$ lattice to be $239 \mathrm{~kJ} / \mathrm{mol}$ and $243 \mathrm{~kJ} / \mathrm{mol}$, respectively, which may explain the low solubility of these oxides in YAG.

Further calculations have shown the association of oppositely charged mobile defect species (clustering) to be energetically favoured. Such effects can reduce the formation energy and enhance the stability of lattice defects.

Finally the authors have calculated the energies of reduction and oxidation reactions in YAG. The redox energies for the processes investigated indicated that YAG will resist both hole and electron creation by redox reactions.

\section{Acknowledgement}

The authors are grateful to Dr R. A. Jackson (University of Keele, UK) for valuable assistance.

\section{References}

1. Catlow, C. R. A., James, A., Mackrodt, W. C. \& Stewart, R. F., Defect energies in alpha- $\mathrm{Al}_{2} \mathrm{O}_{3}$ and rutile $\mathrm{TiO}_{2}$. Phys. Rev. B, 25 (1982) 1006-26.

2. Dienes, G. J., Welsh, D. O., Fisher, C. R., Hatcher, H. D., Lazareth, O. \& Shamberg, M., Shell model calculations of some point defect properties in alpha- $\mathrm{Al}_{2} \mathrm{O}_{3}$. Phys. Rev. B, 11 (1975) 3060-71.

3. Mackrodt, W. C., Calculated point defect, association and migration energies in $\mathrm{MgO}$ and alpha- $\mathrm{Al}_{2} \mathrm{O}_{3}$. In Advanced Ceramics, Vol. 10, ed. W. D. Kingery. American Ceramic Society, 1984, pp. 62-78.

4. Catlow, C. R. A., Corish, J., Hennessy, J. \& Mackrodt, W. C., Atomistic simulation of defect structures and ion transport in alpha- $\mathrm{Fe}_{2} \mathrm{O}_{3}$ and alpha- $\mathrm{Cr}_{2} \mathrm{O}_{3} . J$. Am. Ceram. Soc., 71 (1988) $42-9$

5. Lewis, G. V., Computer simulation of the defect structure and PTC properties in $\mathrm{BaTiO}_{3}$. $\mathrm{PhD}$ Thesis, University College, University of London, 1984.

6. Allan, N. L. \& Mackrodt, W. C., The calculated defect properties of $\mathrm{La}_{2} \mathrm{CuO}_{4}$ related to high $T_{\mathrm{c}}$-superconductivity. Phil. Mag. A, 58 (1988) 555-69.

7. Hsu, Ta-Lin, $A$ Nd-YAG Laser Bibliography. Materials Research Center, Allied Chem. Corp., Morristown, New Jersey, 1973.

8. Gazza, G. E. \& Dutta, S. K., US Patent 37677 45, 27 April 1973.

9. de With, G., Preparation, microstructure, and properties of $\mathrm{Y}_{3} \mathrm{Al}_{5} \mathrm{O}_{12}$ ceramics. Philips J. Res., 42 (1987) 119-30.

10. Mulder, C. A. M. \& de With, G., Translucent $\mathrm{Y}_{3} \mathrm{Al}_{5} \mathrm{O}_{12}$ ceramics: Electron microscopy characterisation. Solid State Ionics, 16 (1985) 81-6.

11. Schuh, L., Metselaar, R. \& de With, G., Electrical conductivity study of defects in $\mathrm{Zr}$-doped YAG. Sci. Ceram., 14 (1987) 973-8.

12. Schuh, L., Metselaar, R. \& de With, G., Electrical transport properties of Ca- and $\mathrm{Mg}$-doped YAG ceramics. J. Appl. Phy's., 66 (1989) 2627-32.

13. Leslie, M., Program CASCADE: Description of data sets for use in crystal calculations. SERC Daresbury Report DL/SCI/TM 31 T, 1982.

14. Mott, N. F. \& Littleton, M. J., Conduction in polar crystals, electrolytic conduction in solid salts. Trans. Faraday Soc., 34 (1938) 485-99.

15. Catlow, C. R. A., Computer modelling of ionic solids. $J$. Phys. Paris, Suppl., 41 (1980) C6-53 C6-60.

16. Catlow, C. R. A., Dixon, M.\& Mackrodt, W. C., Interionic potentials in ionic solids. In Lecture Notes in Physics, Vol. 166, ed. C. R. A. Catlow \& W. C. Mackrodt. Springer Verlag, Berlin-Heidelberg-New York, 1982, pp. 130-61.

17. Colbourn, E. A. \& Kendrick, J., Ab-initio calculations for defects in the solid state. In Lecture Notes in Physics, Vol. 166, ed. C. R. A. Catlow \& W. C. Mackrodt. Springer Verlag, Berlin-Heidelberg-New York, 1982, pp. 67-81.

18. Dick, B. G. \& Overhauser, A. W., Theory of the dielectric constant of alkali halide crystals. Phys. Rev., 112 (1958) $90-103$

19. Lidiard, A. B. \& Norgett, M. J., Computational Solid State Physics. Plenum Press, New York, 1972, pp. 1-165.

20. Norgett, M. J., Atomic Energy Research Establishment Report No. AERE R7605, 1972.

21. Catlow, C. R. A. \& Mackrodt, W. C., Theory of simulation for lattice and defect energy calculations in crystals. In Lecture Notes in Physics, Vol. 166, ed. C. R. A. Catlow \& W. C. Mackrodt. Springer Verlag, Berlin-Heidelberg-New York, 1982, pp. 3-20.

22. Kitaeva, V. F., Zharikov, E. V. \& Christyi, I. L., The properties of crystals with garnet structure. Phys. Stat. Sol. (a), 92 (1985) 475-88. 
23. Wolfmeier, U. H. \& Gunßner, W., Landholdt-Börnstein, Bd 12 III, neue Serie, Elastic, thermoelastic and photoelastic properties, ed. K.-H. Hellwege, Berlin, 1978, p. 356-57.

24. Neiman, A. Ya., Tkachenko, E. V. \& Zhukovskii, V. M., Nature of defect formation in complex oxides of the composition $\mathrm{Me}_{3} \mathrm{E}_{5} \mathrm{O}_{12}$ with a garnet structure. Dokl. Akad. Nauk SSSR, 240 (1978) 876-9.

25. Mackrodt, W. C., Defect energetics and their relation to non-stoichiometry in oxides. Solid State Ionics, 12 (1984) 175-88.

26. Weast, R. C. (ed.), Handbook of Chemistry and Physics. CRC-Press, Florida Boca Raton, 63rd edition, 1982-83, pp. E68.

27. Islam, M. S., Leslie, M., Tomlinson, S. M. \& Catlow, C. R. A., Computer modelling studies of defects and valence states in $\mathrm{La}_{2} \mathrm{CuO}_{4}$. J. Phys. C: Solid State, 21 (1988) L109-L177.
28. Catlow, C. R. A., Corish, J., Diller, K. M., Jacobs, P. W. M. \& Norgett, M. J., Atomic Energy Research Establishment Report AERE TP 713, 1977, pp. 1-145.

29. Rotman, S. R., Tandon, R. P. \& Tuller, H. L., Defect property correlations in garnet crystals: The electrical conductivity and defect structure of luminescent ceriumdoped YAG. J. Appl. Phys., 57 (1985) 1951-5.

30. Schuh, L., Microstructure and defect chemistry of YAGceramics. PhD Thesis, Technical University Eindhoven, The Netherlands, 1989.

31. Röschmann, P., Kinetics of cation site exchange in mixed garnets. J. Phys. Chem. Solids, 42 (1981) 337-50.

32. Haneda, H., Miyazawa, Y. \& Shirasaki, R., Oxygen diffusion in YAG investigated by $\mathrm{O}^{18}$ tracer experiments. $J$. Cry'st. Growth, 68 (1984) 581-2. 